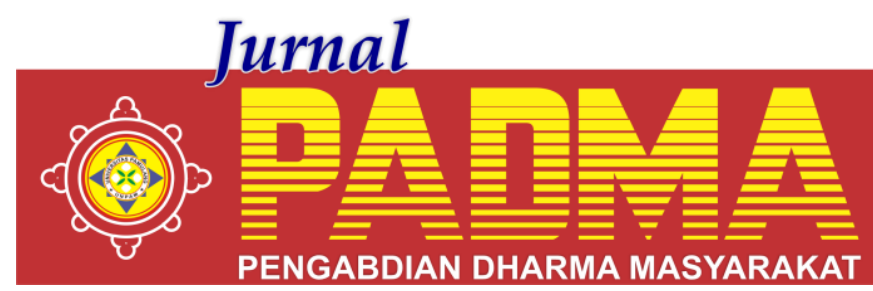

VOLUME 1, NOMOR 1, JANUARI 2021

\title{
MENUMBUHKAN SEMANGAT PENGUSAHA MUDA SISWA SMK MUHAMMADIYAH PARUNG
}

\author{
${ }^{1 *}$ Imbron, ${ }^{2}$ Suharni Rahayu, ${ }^{3}$ Irmal, ${ }^{4}$ Nurmin Arianto, ${ }^{5}$ Priehadi Dhasa Eka \\ Universitas Pamulang, Tangerang Selatan, Banten, Indonesia \\ *dosen02455@unpam.ac.id
}

\begin{abstract}
Abstrak
Tujuan kegiatan ini adalah menumbuhkan semangat pengusaha muda ini sangat dibutuhkan sesuai dengan kebutuhan para siswa saat ini. Oleh sebab itulah pada PKM ini akan diberikan penyuluhan menumbuhkan semangat pengusaha muda siswa SMK Muhammadiyah Parung. Dalam kegiatan ini metode yang diterapkan diharapkan dapat memberikan kemudahan kepada para mahasiswa SMK Muhammadiyah Parung. Metode yang digunakan adalah metode diskusi kelompok, sharing, tanyajawab, praktik yang di damping oleh pemateri. Pada metode penjelasan, setiap instruktur menyampaikan materi terkait dan membuat tampilan visual berupa slide power point yang ditampilkan ke layar dengan LCD proyektor. Hasil kegiatan memberikan pemahaman baru kepada siswa dalam melakukan pengelolaan binis tidak harus selalu dengan nominal uang yang besar, atau mekanisme yang rumit. Mereka dapat melakukannya secara berkelompok, atau sendiri dari rumah. Siswa dapat mendapatkan ilmu pengetahuan baru, sehingga bisa dimaksimalkan potensi diri dengan kreatif dan inovatif.
\end{abstract}

Kata Kunci: Wirausaha

Abstract
The purpose of this activity is to foster the spirit of young entrepreneurs is needed in accordance with the needs of students today. That is why the PKM will be given counseling to foster the enthusiasm of young entrepreneurs of SMK Muhammadiyah Parung students. In this activity the method applied is expected to provide convenience to students of Muhammadiyah Parung High Schools. The method used is the method of group discussion, sharing, question and answer, practice accompanied by the speaker. In the explanation method, each instructor conveys related material and makes a visual display in the form of a power point slide that is displayed on the screen with the projector's LCD. The results of activities provide new understanding to students in managing business not necessarily with large amounts of money, or complicated mechanisms. They can do it in groups, or alone from home. Students can get new knowledge, so they can maximize their potential with creativity and innovation.

Keywords: Entrepreneurship

\section{PENDAHULUAN}

SMK Muhammadiyah Parung memiliki nama baik yang cukup bagus di mata masyarakat. Salah satu sekolah terbaik yang ada di Parung Bogor, SMK ini selalu berupaya mencetak lulusan yang tidak hanya cakap dalam bidang akademis dan non akademis, tetapi juga memiliki karakter yang siap bersaing dalam secara intelektual. Sebagai salah satu SMK Terbaik di Parung Bogor, SMK Muhammadiyah Parung berkewajiban membentuk mindset dan ketrampilan peserta didiknya agar mampu bersaing di era milenial saat ini. Salah satunya adalah dengan mengembangkan skill kewirausahaan para siswa. Agar Siswa dapat memiliki semangat berwirausaha yang terstruktur sejak dini, mampu memetakan diri dan dapat membuat branding diri dan produk yang dibuat

Perlu upaya menumbuhkan kembali jiwa kewirausahaan siswa. Upaya itu tentu perlu dukungan dari semua pihak, tidak hanya sekolah, kewirausahaan merupakan suatu proses untuk mengembangkan atau menerapkan suatu ide inovatif dalam memanfaatkan peluang mendapatkan sesuatu yang bernilai. Sehingga, pengembangan potensi itu sangat baik diterapkan dalam diri sebagai bentuk manajerial dalam kehidupan.

Banyak orang yang keliru menganggap berwirausaha itu hanya berdagang saja. Padahal, berwirausaha itu bisa berupa apa 
saja. Perlu mengubah mindset pikiran agar siswa memiliki jiwa berwirausaha sejak dini. Karena sekarang ini, ketika lulus sekolah, anak-anak lebih menyukai sesuatu hal yang serba instan, yaitu lebih memilih bekerja menjadi buruh, dibandingkan membuka usaha atau berwirausaha.

Sekolah adalah untuk mencetak siswa agar memiliki suatu keahlian sebagai bekal menghadapi dunia kerja. Tapi akan lebih baik, jika siswa berinovasi untuk membuka usaha dan memiliki usaha sendiri. Dengan begitu dapat memberikan kesempatan kerja bagi orang lain. Dengan harapan di masa depan dengan berwirausaha pendapatan akan berbeda. Ketika menjadi pekerja, maka penghasilannya hanya mengsiswalkan gaji dari perusahaan yang diterima setiap bulan dengan nilai gaji yang sama. Sedangkan menjadi pengusaha pendapatannya tak terbatas, bergantung dari diri inovasi sendiri. Kalau ingin berpenghasilan banyak, usahanya lebih rajin dan waktupun kita yang menentukan. Hal itu sangat berbeda dengan pekerja.

Bagi sebagian orang, berjualan atau berwirausaha bukanlah suatu pekerjaan, melainkan sebuah profesi. Sedangkan menjadi buruh adalah suatu pekerjaan yang bisa disebut bekerja. Namun, tak jarang orang merasa malu jika dirinya berjualan atau usaha sendiri. Berbeda jika dirinya bekerja sebagai buruh, dengan pakaian rapi. Tetapi waktu diatur perusahaan dan pendapatan terbatas.

Kegiatan Pengabdian Kepada Masyarakat dari tim dosen dan mahasiswa Universitas Pamulang hadir di SMK Muhammadiyah Parung dalam bentuk pelatihan. Pelatihan ini akan melakukan pendekatan kekinian dengan metode diskusi berkelompok sehingga dapat lebih mudah dipahami oleh siswa SMK Muhammadiyah Parung yang rata-rata adalah pemuda dan remaja siswa yang up to date dengan keadaan saat ini. Beberapa materi tentang kewirausahaan, khususnya untuk siswa yang mendapatkan uang dari pekerjaan sampingan bisa menjadi langkah awal yang tepat untuk dilaksanakan oleh remaja menuju kemandirian ataupun kebebasan finansial atau financial freedom. Hal ini tentu akan bisa didapatkan pada saat sang anak ataupun remaja telah lulus kuliah dan mendapat pekerjaan, atau justru sudah memiliki kehendak Semangat pengusaha muda sambilan (part time) saat masih sekolah pun kuliah.

Uang yang diterima sebagai upah Semangat pengusaha muda itu apabila dikelola dengan baik sangat memberi arti, dapat menjadi peranan penting dalam pembentukan jati diri anak guna mempersiapkannya di masa mendatang. Sangat diharapkan dari pelatihan ini para siswa di SMK Muhammadiyah Parung dapat Semangat pengusaha mudanya degan cara yang sederhana, dan dapat membentuk karakter hemat dan bijak dalam Semangat pengusaha muda.

\section{METODE}

Dalam kegiatan ini metode yang diterapkan diharapkan dapat memberikan kemudahan kepada para mahasiswa SMK Muhammadiyah Parung Metode yang digunakan adalah metode diskusi kelompok, sharing, tanyajawab, praktik yang di damping oleh pemateri. Pada metode penjelasan, setiap instruktur menyampaikan materi terkait dan membuat tampilan visual berupa slide power point yang ditampilkan ke layar dengan LCD proyektor.

Instruktur dalam menyampaikan penjelasan juga memasukkan unsur ?sharing? atau berbagi pengalaman mengenai pengelolaan binis sederhana yang dilakukan oleh siswa dan materi yang telah dimiliki pemateri, dengan pertimbangan tersebut diharapkan dapat memberikan gambaran lebih jelas kepada peserta. Pada metode praktik, peserta berkelompok dan dengan pendampingan panitia mahasiswa bergantian menyusun perencanaan binis secara bergantian berkaitan dengan temannya. Peserta diajarkan bagaimana acara menyusun daftar kebutuhan dan mereka diperbolehkan memberikan penambahan daftar keinginan yang ingin mereka capai beserta strategi untuk mencapainya. Dengan demikian siswa tidak hanya sekedarterarah, dengan menggunakan pengelolaan binis sederhana yang jelas.

\section{HASIL DAN PEMBAHASAN}

Kegiatan Pengabdian Kepada Masyarakat ini berkaitan erat dengan menumbuhkan semangat pengusaha muda 
pada siswa. Pemahaman akan pentingnya melatih diri untuk berwirausaha haruslah disadari oleh usia remaja, dan sekolah menengah harus bisa membimbing 23 setiap pelajar untuk dapat memahami bisnis dengan baik. Meskipun sebenarnya sekolah lebih utama, akan tetapi pemahaman tentang memulai bisnis perlu diberikan, untuk kemandirian individu. Fokus utama dalam aktivitas menumbuhkan semangat pengusaha muda ini memang harusnya disebar secara tersirat dalam mata pelajaran ekonomi dan akuntansi. Hal itu haruslah didasarkan pada intensitas perencanaan, kesiapan berpartisipasi dalam kehidupan sebagai pribadi yang independent, dan keterarahan individu-individu kepada tujuan. Didukung minat mereka untuk berbisnis yang sangat kuat.

Perilaku yang konsumtif sering tak disadari. Alhasil, banyak orang yang begitu konsumtif sehingga perlahan binisnya menjadi bermasalah. Uang yang diterima mungkin tinggi namun tidak ada yang bisa ditabung di akhir bulan. Bila Siswa pernah terpikir kenapa belum ada dana yang ditabung padahal Siswa sudah memiliki uang saku yang melebihi jumlah pengeluaran yang seharusnya, mungkin perilaku konsumtif Siswa yang menjadi penyebabnya. Remaja yang konsumtif biasanya membeli barang yang sebenarnya tidak terlalu ia butuhkan, membelanjakan uang untuk keperluankeperluan yang tidak penting, gaya hidup yang terlalu hura-hura, dan sebagainya. Untuk itui dibuatlah solusi, tahan selera Siswa. Siswa harus mementingkan kebutuhan; mana yang harus dipenuhi dan mana yang sebenarnya kurang penting, dalam artian, terpenuhi atau tidaknya hal tersebut tidak akan mempengaruhi Siswa.

Bila Siswa sudah memiliki suatu barang, usahakan agar tidak membeli barang dengan fungsi yang sama namun harganya lebih mahal. Buat apa punya dua barang dengan fungsi yang sama? Meski mungkin, yang lebih mahal tentu lebih bagus dan lengkap fungsinya. Siswa juga harus tahu tujuan Siswa dalam mengalokasikan dana. Bila Siswa tidak bijak dalam menetapkan tujuan pembelanjaan, Siswa hanya akan 24 membelanjakan uang Siswa untuk berbagai keperluan yang sebenarnya tidak perlu.
Tak bisa dipungkiri, anak muda memang senang menghabiskan waktu untuk berkumpul/nongkrong, menikmati sesuatu yang sedang tren, berusaha untuk terus sejalan dengan perkembangan terkini dalam berbagai bidang, dan sebagainya. Apalagi bagi siswa yang belum memiliki tanggungan atau masih lajang. Karena belum memiliki tanggungan, ia merasa belum bertanggung jawab untuk Semangat pengusaha mudanya karena pendapatannya hanya untuknya. Jadi, anggapan bahwa penghasilannya hanya untuknya seakan melekat dalam dirinya.

Oleh karena itu, siswa kerap menghabiskan uang untuk memanjakan dirinya tanpa disadari. Perlahan binisnya pun menjadi tak terkontrol. Setiap bulan uang habis tanpa sisa untuk ditabung, menunggu bulan depan untuk gajian kembali. Bila pun ada sejumlah dana yang tersisa, Siswa umumnya menggunakan uang tersebut untuk bersenang-senang, bukan menabung atau berinvestasi.

Solusi sepenuhnya ada di dalam diri Siswa. Harus mencoba untuk menemukan pola yang tepat ketika membelanjakan uang. Bila Siswa merasa bahwa selama ini sudah terlalu banyak menghamburkan uang untuk bersenang-senang, mungkin Siswa benar. Meskipun sekarang ini Siswa belum memiliki tanggungan, siswa harus mencoba untuk berhemat, mengatur pengeluaran dengan membandingkan mana yang prioritas dan mana yang tidak begitu mendesak.

Tidak Mempersiapkan Dana Darurat Sehingga Kebingungan Saat Keperluan Mendadak Muncul Dana darurat tidak hanya permasalahan yang harus dipersiapkan oleh orang akan sangat bermanfaat bila nantinya ada saja ke dewasa. Siswapun memerlukan ini untuk membayar perluan mendadak yang harus dipenuhi sementara uang Siswa tidak cukup untuk menutupinya. Siswa mungkin belum terpikir untuk mempersiapkan dana darurat, atau bila pun sudah terpikir, uang Siswa sudah habis lebih dulu sebelum benarbenar memulai untuk menyiapkan dana darurat.

Solusinya dari sekarang Siswa harus bisa menyisihkan sejumlah uang yang kemudian dialokasikan khusus untuk dana darurat. Misalnya, dalam sebulan, cobalah sisihkan uang saku Siswa per bulan, misalnya 20\% dari gaji Siswa, khusus untuk 
dana darurat. Nantinya, jangan pernah sentuh uang tersebut selain dari keperluan mendesak.

Salah satu masalah binis yang sering dihadapi Siswa adalah kurangnya kesadaran bahwa seturut waktu uang yang ia miliki akan berkurang nilainya terutama ketika inflasi terjadi. Setiap Siswa kerap mengabaikan fakta bahwa pendapatan hari esok bisa saja lebih rendah ketimbang hari ini. Maka dari itu demi mempersiapkan diri dari kemungkinan-kemungkinan yang menyesakkan ke depannya, jangan biarkan uang yang Siswa miliki saat ini diam tak menghasilkan. Siswa bisa mencari sumber penghasilan baru seperti berbisnis atau memulai pekerjaan sampingan. Siswa bahkan bisa berinvestasi terutama karena beragam instrumen investasi.

Pengelolaan binis sederhana untuk siswa SMK Muhammadiyah Parung diharapkan mampu memberikan visi dan semangat baru dalam upaya siswa meraih cita-cita. Pengelolaan binis sederhana ini adalah dasar yang akan digunakan oleh siswa untuk membentuk mindset, kemampuan berpikir hemat, cermat dan ekonomis. Sehingga akan berdampak pada perilakunya menggunakan uang baik di sekolah maupun di rumah. Dengan pengelolaan binis yang mantab, siswa akan lebih bisa fokus dalam belajar, dapat mengatur diri dengan baik, memiliki tujuan yang pasti, serta akan membuatnya mampu berpikir secara rasional. Siswa akan lebih mengenal dirinya sendiri, potensi yang dimiliki serta upaya yang dapat dilakukan untuk meraih keinginannya dan dapat menikmati prosesnya dengan benar.

\section{PENUTUP}

Hasil kegiatan PKM di SMK Muhammadiyah Parung berjalan dengan lancar. Siswa terlihat fokus dan antusias dalam pengikuti pelatihan ini. Selain itu kegiataan ini memberikan motivasi baru bagi siswa untuk lebih semangat untuk menjadi wirausaha muda. Siswa mendapatkan pengalaman dan support untuk menyusun rencana usahanya ke depan sebagai persiapan untuk menghadapi persiapan persaingan di era glonbalisasi ini, kalaupun siswa tidak dapat bekerja di perusahaan besar tapi mereka sudah siap jika mengembangkan bisnisnya secara madiri, dan Siswa mendapatkan ilmu pengetahuan untuk mengmbangkan diri, sehingga bisa digunakan untuk memaksimalkan potensi diri.

\section{DAFTAR PUSTAKA}

Achmad, Nur. 2015. Kewirausahaan: Suatu Alternatif Lain Menuju Kesuksesan. Surakarta: BPK FEB UMS.

Ajimat, A., Sunarsi, D., \& Sidiq, F. (2020). Berwirausaha Memanfaatkan Media Sosial Pada Daerah Sepatan. ADI Pengabdian Kepada Masyarakat, 1(1), 69-76.

alam Mendirikan UMKM Dan Efektivitas Promosi Melalui Online Di Kota Tangerang Selatan. Jurnal Ilmiah MEA (Manajemen, Ekonomi, \& Akuntansi), 4(3), 702-714.

Drucker. Peter. F. 1993. Inovasi Dan Kewiraswastaan. Jakarta:

Effendy, A. A., \& Sunarsi, D. (2020). Persepsi Mahasiswa Terhadap Kemampuan D

Erlangga. Effendy, Mochtar. 2010. Kewirausahaan (Entrepreneurship) Tuntunan Untuk Praktisi. Yayasan Penerbit Al-Mukhtar: Palembang.

Nurjaya, N., Affandi, A., Erlangga, H., Sunarsi, D., \& Jasmani, J. (2021). The Effect of Product Promotion and Innovation Activities on Marketing Performance in Middle Small Micro Enterprises in Cianjur. Budapest International Research and Critics Institute (BIRCIJournal): Humanities and Social Sciences, 4(1), 528-540.

Pawar, A., Sudan, K., Satini, S., \& Sunarsi, D. (2020). Organizational Servant Leadership. International Journal of Educational Administration, Management, and Leadership, 63-76. 